\title{
Diagnosis of allergic sensitization in patients with allergic rhinitis and asthma in a tropical environment
}

\section{Diagnóstico de la sensibilización alérgica en pacientes con rinitis alérgica y asma en un ambiente tropical}

Mario Sánchez-Borges, ${ }^{1}$ Arnaldo Capriles-Hulett, ${ }^{2}$ Joselit Torres, ${ }^{3}$ Ignacio Javier Ansotegui-Zubeldia, ${ }^{4}$ Adriana Castillo, ${ }^{3}$ Ariadne Dhersy, ${ }^{3}$ Xiomara Monzón ${ }^{3}$

\begin{abstract}
Background: Few studies in tropical developing countries have utilized molecular diagnosis to characterize allergen-specific responses to aeroallergens.

Objective: To investigate the in vivo and in vitro responses of IgE antibodies to inhalant allergens in allergic patients with rhinitis and/or asthma.

Methods: A prospective study in which patients with allergic rhinitis and/or asthma were included. Skin prick tests with 16 inhalant extracts of allergens were carried out and total and specific IgE levels for allergens and their molecular components in the serum were determined.

Results: In a total of 189 patients, $73.5 \%$ showed high levels of total IgE in the serum. The prick tests were positive for the following allergens: Dust mite extracts; more than $60 \%$, cat; $29.6 \%$, dog; $23.4 \%$, and Periplaneta Americana; $21.6 \%$. Specific IgE for Dermatophagoides farinae and Pteronyssinus was present in $66.6 \%$ of the patients; for Blomia tropicalis; in $45.0 \%$, for Ascaris lumbricoides; in $24.7 \%$, for cat; in $17.3 \%$, for parrot feathers; in $14.8 \%$, and for Penicillium notatum; in $12.3 \%$. IgE antibodies to mite allergens of group 1 and 2 were present in $59.0 \%$ and $70.1 \%$ of the sera; $39.1 \%$ contained IgE to rBlo t5, $30.4 \%$ contained rBla g4, $19.9 \%$ contained rFel d1, $11.8 \%$ contained rArt v3, $11.2 \%$ contained Der p10, $9.9 \%$ contained rBla g2, $9.3 \%$ contained rPer a7, $9.3 \%$ contained $\mathrm{nFel} \mathrm{d2}$, and $8.7 \%$ contained rCan $\mathrm{f1}$.

Conclusions: This study confirms that mites are the main sensitizing agents in patients with respiratory allergic diseases in a tropical environment. There was a good correlation between the results of the skin tests and the results of the in vitro tests.
\end{abstract}

Keywords: Allergic rhinitis; Asthma; Molecular diagnosis; Mites

How to cite this article: Sánchez-Borges M, Capriles-Hulett A, Torres J, Ansotegui-Zubeldia IJ, Castillo A, Dhersy A, Monzón X. Diagnosis of allergic sensitization in patients with allergic rhinitis and asthma in a tropical environment. Rev Alerg Mex. 2019;66(1):44-54

ORCID

Mario Sánchez-Borges, 0000-0002-9308-6418; Arnaldo Capriles-Hulett, 0000-0002-9855-5391; Joselit Torres, 0000-0002-3100-5141; Ignacio Javier Ansotegui-Zubeldia, 0000-0002-6942-1511;

Adriana Castillo, 0000-0002-4381-1941; Ariadne Dhersy, 0000-0002-8246-724X; Xiomara Monzón, 0000-0001-7206-2305

${ }^{1}$ Clínica El Ávila, Servicio de Alergia e Inmunología Clínica, Caracas, Venezuela

${ }^{2}$ Centro Médico Docente La Trinidad, Departamento de Alergia e Inmunología Clínica, Caracas, Venezuela
${ }^{3}$ Instituto Docente de Inmunodiagnóstico, Caracas, Venezuela

${ }^{4}$ Hospital Quironsalud, Departamento de Alergia e Inmunología, Vizcaya, España 


\section{Resumen}

Antecedentes: Pocos estudios en países tropicales y en desarrollo han utilizado el diagnóstico molecular para caracterizar las respuestas específicas a los aeroalérgenos.

Objetivo: Investigar las respuestas de anticuerpos IgE in vivo e in vitro a alérgenos inhalantes en pacientes alérgicos con rinitis o asma.

Métodos: Estudio prospectivo que incluyó pacientes con rinitis alérgica o asma. Se realizaron pruebas cutáneas por punción con 16 extractos de alérgenos inhalantes y se determinaron los niveles de IgE total y específica para alérgenos y sus componentes moleculares en el suero.

Resultados: De 189 pacientes, en 73.5 \% se observó niveles elevados de IgE total en el suero. Las pruebas de punción fueron positivas a los siguiente alérgenos: extractos de ácaros más de $60 \%$, gato $29.6 \%$, perro $23.4 \%$ y Periplaneta americana $21.6 \%$. La IgE específica para Dermatophagoides farinae y pteronyssinus estuvo presente en $66.6 \%$, para Blomia tropicalis, Ascaris lumbricoides, gato, plumas de perico, Penicillium notatum en 45.0, 24.7, 17.3, 14.8 y $12.3 \%$, respectivamente. Anticuerpos de clase IgE a alérgenos de ácaros de los grupos 1 y 2 estuvieron presentes en 59.0 y $70.1 \%$ de los sueros; 39.1, 30.4, 19.9, 11.8, 11.2, 9.9, 9.3, 9.3 y $8.7 \%$ contenían IgE a rBlot5, rBla g4, rFel d1, rArt v3, Derp 10, rBla g2, rPer a7, nFel d2 y rCan $\mathrm{f1}$, respectivamente.

Conclusiones: Se confirma a los ácaros como los principales agentes sensibilizantes en pacientes con enfermedades alérgicas respiratorias en el trópico. Existió buena correlación entre los resultados de las pruebas cutáneas y las pruebas in vitro.

Palabras clave: Rinitis alérgica; Asma; Diagnóstico molecular; Ácaros

Correspondence: Mario Sánchez-Borges sanchezbmario@gmail.com
Received: 2018-11-24

Accepted: 2019-01-20

DOI: $10.29262 /$ ram.v66i1.570

\section{Background}

The allergic diseases that involve the respiratory tract, rhinitis, asthma, and their comorbidities, represent a major public health concern all over the world, resulting in a significant burden on the patients' quality of life and the use of healthcare resources. ${ }^{1,2}$ The prevalence of allergic rhinoconjunctivitis in Venezuelan children who are 6 to 7 years of age is of $20.4 \%$, and the prevalence in 13 to 14 year olds is of $24.9 \%$, whereas the prevalence of asthma in 6-7 year olds is of $20 \%$ and, in 13-14 year olds, the prevalence is $15.4 \%{ }^{3}$

Previous investigations that have utilized skin prick tests with commercial extracts have shown that the allergens that induce sensitization in patients with rhinitis and asthma in Caracas are, by order of frequency: domestic mites, dogs, cats, cockroaches, moulds, pollens from grass, bird feathers, and pollens from weeds and trees., ${ }^{4,5,6}$
For clinical practice, the diagnosis of respiratory allergies is performed routinely through patient questioning, physical examination, immediate-type skin testing, and/or the measurement of total and allergen-specific $\operatorname{IgE}$ in the serum. For rhinitis, a cytological evaluation of nasal smears and nasal provocation tests are also used in some centers. ${ }^{7}$ For asthmatic patients, spirometry and the response to bronchodilators are useful to confirm the diagnosis and to follow the evolution of the disease and its response to the treatment; while bronchial provocation tests with methacholine and allergens can be used to confirm nonspecific and specific bronchial hyperresponsiveness, respectively. ${ }^{8,9}$

Recent developments in molecular biology and genetics have provided a better characterization of allergenic molecules, and the investigation of specific IgE to natural and recombinant allergenic components has been increasingly incorporated as complementa- 
ry tests proposed for the study of allergen sensitization..$^{10}$ The high prevalence, associated morbidity, and socioeconomic burden of respiratory allergies justify the realization of investigations that contribute to a better characterization of their etiologic factors and the implementation of novel diagnostic, prophylactic, and immunotherapeutic methods that are applicable in patients who suffer from those ailments.

The objectives of this study were to investigate the in vitro $\mathrm{IgE}$ responses to inhalant allergens in allergic patients with rhinitis and/or asthma from Caracas, Venezuela, and to compare those responses with the results of skin tests performed with commercial crude allergenic extracts.

\section{Methods}

Unselected patients who attended three Allergy Services located in Caracas, Venezuela, ("Hospital San Juan de Dios", "Clínica El Ávila" and "Instituto Docente de Inmunodiagnóstico"), were prospectively included in the study after the diagnosis of rhinitis, rhinoconjunctivitis, rhinosinusitis, and/or asthma was confirmed according to current guideline recommendations. ${ }^{11,12}$ Patients of any age or gender with any diagnostic features that are compatible with those diseases, and at least one positive immediate-type skin test to aeroallergens, were included. Pregnant women, individuals who suffer from severe systemic diseases (malignant neoplasia, immunodeficiencies, diabetes mellitus, nephropathies, hematological or psychiatric diseases), and patients with severe dermatological conditions or dermatographism interfering with skin testing were excluded.

Clinical information about age, gender, frequency of the symptoms, and quality-of-life parameters were used to classify the severity of rhinitis according to ARIA guidelines, ${ }^{11}$ whereas symptom frequency and spirometry permitted to classify the severity and control of asthma according to the Global Initiative for Asthma guidelines. ${ }^{12}$ In order to be included in the study, patients and/or their parents signed informed consent forms. The protocol followed the Declaration of Helsinki, current Good Clinical Practices, and was approved by the Institutional Review Boards of all three participating institutions.

\section{Skin tests}

The skin prick tests were performed using disposable lancets (Prick Lancetter, Hollister-Stier, Spokane,
Washington), with the following allergenic extracts: Dermatophagoides pteronyssinus (50000 DBU/mL), Dermatophagoides farinae (50000 DBU/mL), Blomia tropicalis $(30000 \mathrm{DBU} / \mathrm{mL})$, dog $(50000 \mathrm{DBU} /$ $\mathrm{mL}$ ), cat (50000 DBU/mL), Periplaneta americana $(1 \mathrm{mg} / \mathrm{mL})$, Penicillium notatum $(20000 \mathrm{DBU} / \mathrm{mL})$, Aspergillus fumigatus (20000 DBU/mL), Cladosporium herbarum (20000 DBU/mL), Alternaria alternata $(20000 \mathrm{DBU} / \mathrm{mL})$, Candida albicans (20000 DBU/mL), Cynodon dactylon (Bermuda grass) (50000 DBU/mL), Ambrosia artemisiifolia (50000 DBU/mL), Plantago lanceolata (50000 DBU/ $\mathrm{mL})$, Amaranthus retroflexus (10000 DPU/mL), and Taraxacum officinale (10000 DPU/mL) (Bial Industrial Farmacéutica, Zamudio, Bizkaia, Spain).

Glycerol saline solution and $1 \mathrm{mg} / \mathrm{mL}$ of histamine phosphate were used as negative and positive controls, respectively. The reading was done at 15 minutes, and wheal diameters were recorded. Wheals that were $3 \mathrm{~mm}$ greater than the negative control were regarded as positive. Antihistamines were omitted for 96 hours before the skin tests.

Total and specific lgE

The total IgE in the serum was quantified by means of an enzyme-linked immunosorbent assay (ELISA) (Euroimmun, Lübeck, Germany). The results were expressed in international units $/ \mathrm{mL}(\mathrm{IU} / \mathrm{mL})$.

Allergen-specific IgE antibodies in the serum were measured through an immunoblot assay. For this purpose, strips containing the respective allergens were incubated with 1:100 dilutions of the patients' sera at room temperature for 30 minutes. The allergen-bound IgE was then detected by incubation with monoclonal anti-human IgE conjugated with alkaline phosphatase for 30 minutes at room temperature. The reaction was revealed by adding chromogenic substrate NBT/BCIP for 10 minutes. The automatic reading was done with EUROBlotOne (Euroimmun, Lübeck, Germany).

The IgE antibodies to the following natural allergens were investigated: Bermuda grass, Lolium perenne, Sorghum halepense, mugwort (Artemisia vulgaris), Taraxacum officinale, Plantago lanceolata, Amaranthus retroflexus, cat, dog, parrot feathers, chicken feathers, duck feathers, goose feathers, Penicillium notatum, Cladosporium herbarum, Aspergillus fumigatus, Candida albicans, Alternaria alternata, Dermatophagoides pteronyssinus, 
Dermatophagoides farinae, Blomia tropicalis, and Periplaneta americana. Additionally, specific IgE antibodies for Ascaris lumbricoides, Echinococcus granulosus, and Anisakis simplex were measured.

The serum specific IgE levels to the following allergen components were investigated: Timothy grass: $\mathrm{rPhl} \mathrm{p1,} \mathrm{rPhl} \mathrm{p} 7, \mathrm{rPhl} \mathrm{p} 12, \mathrm{rPhl} \mathrm{p} 5$. Artemisia vulgaris: rArt v1, rArt v3, rArt v4. Cat: $\mathrm{rFel} \mathrm{d} 1$, Fel d2 (Geline serum albumin).Dog: rCan f1, Can f3 (Canine serum albumin). Dermatophagoides pteronyssinus: Der p1, Der p2, Der p10. Dermatophagoides farinae: Der f1, Der f2. Blomia tropicalis: rBlo t5. Blattella germanica: rBla g1, rBla g5, rBla g2, rBla g4. Periplaneta americana: rPer a7.

According to the instructions of the manufacturer, the results of specific IgE were expressed in classes as follows:

- Class 0: $<0.35 \mathrm{kU} / \mathrm{L}$.

- Class 1: 0.35-0.7 kU/L.

- Class 2: 0.7-3.5 kU/L.

- Class 3: 3.5-17.5 kU/L.

- Class 4: 17.5-50 kU/L.

- Class 5: 50-100 kU/L.

- Class $6>100 \mathrm{kU} / \mathrm{L}$.

A result $\geq 0.35 \mathrm{kU} / \mathrm{L}$ ( $\geq$ Class 1 ) was deemed positive for the presence of allergen-specific or component-specific IgE in the serum.

\section{Statistical analysis}

Quantitative variables are presented as mean \pm 1 standard deviation. Pearson's correlation coefficient was applied to correlate skin test results and specific $\operatorname{IgE}$ in the serum, as well as total $\operatorname{IgE}$ and specific IgE levels. A $p$ value $<0.05$ was deemed significant.

\section{Results}

One hundred and eighty-nine patients were included into this study, out of which: $106(56.0 \%)$ were female and $83(43.9 \%)$ were male; the mean age was of $19.41 \pm 16.23$ years old (range: 2 to 67 years of age). One hundred and eighty five patients suffered from rhinitis, rhinitis plus asthma, rhinoconjunctivitis, or rhinosinusitis, while five patients had asthma alone. Most patients had moderate/severe persistent rhinitis $(82.1 \%)$ or moderate/severe intermittent rhinitis $(11.8 \%)$. The severity of asthma was moderate in $83.6 \%$, mild in $8.1 \%$, and intermittent in $8.1 \%$ of the patients. The control assessment determined that asthma was uncontrolled in $61.2 \%$ of the patients, partially controlled in $34.6 \%$, and well controlled in $4.0 \%$ (table 1 ).

The following comorbid conditions were present in the studied patients: atopic dermatitis was present in 20 patients, chronic spontaneous urticaria was present in 16, cutaneous NSAID hypersensitivity

\begin{tabular}{|c|c|c|}
\hline & $\mathrm{n}$ & $\%$ \\
\hline \multicolumn{3}{|l|}{ Gender } \\
\hline Female & 106 & 56.0 \\
\hline Male & 83 & 43.9 \\
\hline \multicolumn{3}{|l|}{ Diagnosis $(n=189)$} \\
\hline Rhinitis & 114 & 60.3 \\
\hline Rhinitis + asthma & 45 & 23.8 \\
\hline Rhinoconjunctivitis & 22 & 11.6 \\
\hline Asthma & 4 & 2.1 \\
\hline Rhinosinusitis & 4 & 2.1 \\
\hline \multicolumn{3}{|l|}{ Severity of rhinitis* $(n=185)$} \\
\hline Mild intermittent & 5 & 2.7 \\
\hline $\begin{array}{l}\text { Moderate/severe } \\
\text { intermittent }\end{array}$ & 22 & 11.8 \\
\hline Mild persistent & 6 & 3.2 \\
\hline Moderate/severe persistent & 152 & 82.1 \\
\hline \multicolumn{3}{|l|}{ Asthma severity ${ }^{* *}(n=49)$} \\
\hline Intermittent & 4 & 8.1 \\
\hline Mild & 4 & 8.1 \\
\hline Moderate & 41 & 83.6 \\
\hline Severe & 0 & 0 \\
\hline \multicolumn{3}{|l|}{ Asthma control ${ }^{\star *}$} \\
\hline Well controlled & 2 & 4.0 \\
\hline Partially controlled & 17 & 34.6 \\
\hline Not controlled & 30 & 61.2 \\
\hline \multirow[t]{2}{*}{$\begin{array}{l}\text { Increased total serum IgE } \\
(>100 \mathrm{IU} / \mathrm{mL})\end{array}$} & $139 / 189$ & 73.5 \\
\hline & \multicolumn{2}{|c|}{$\begin{array}{c}\text { Mean } \pm \text { standard } \\
\text { deviation }\end{array}$} \\
\hline Age (years) & \multicolumn{2}{|c|}{$\begin{array}{c}19.41 \pm 16.23 \\
\text { (range } 2-67)\end{array}$} \\
\hline Total serum IgE (IU/mL) & \multicolumn{2}{|c|}{$756.28 \pm 1105.65$} \\
\hline
\end{tabular}


(urticaria, angioedema) was present in 4, aspirin/ NSAID exacerbated respiratory disease was present in 1, drug-induced maculopapular rash was present in 1 , chronic discoid lupus erythematosus was present in 1, stable systemic lupus erythematosus was present in 1 , hypertension was present in 1, sleep apnea was present in 1 , hypersensitivity to crustaceans was present in 1, hyperthyroidism was present in 1 , and psoriasis was present in 1 .

\section{Total serum IgE}

The mean values of total serum IgE were $756.28 \pm 1105.65 \mathrm{IU} / \mathrm{m}$. Increased levels of total serum $\operatorname{IgE}(>100 \mathrm{IU} / \mathrm{mL})$ were present in 139 patients $(75.3 \%)$. The distribution of total IgE levels in the studied population is shown in figure 1 .

\section{Skin prick tests}

Immediate hypersensitivity tests performed by prick method were positive to mite allergenic extracts in more than $60 \%$ of the patients, followed by cat $(29.6 \%)$, dog $(23.4 \%)$, and Periplaneta americana (21.6\%). Mould, grass pollen, and weed pollen extracts induced positive skin prick tests in less than $10 \%$ of the patients (figure 2). Fourteen patients showed positive prick tests to dermatophagoides extracts and negative tests to blomia tropicalis, while three patients responded exclusively to blomia extract but not to dermatophagoides.

\section{Serum levels of allergen-specific IgE}

Specific IgE for Dermatophagoides farinae and Pteronyssinus was present in the sera of $66.6 \%$ of the patients; for Blomia tropicalis, it was present in $45.0 \%$, for ascaris lumbricoides, it was present in $24.7 \%$, for cat, in $17.3 \%$, for parrot feathers, in $14.8 \%$ and, for Penicillium notatum, in $12.3 \%$. Specific IgE to other allergens, including moulds, pollens, and feathers of other birds, American cockroach, and dog was present in rates lower than $10 \%$ (table 2). Specific IgE to Echinococcus granulosus was present in $7.4 \%$ of the patients, and to Anisakis simplex, in $3.1 \%$. There was a statistically significant positive correlation between total serum IgE and specific IgE to Ascaris lumbricoides (figure 3).

\section{Serum specific IgE to allergen components}

IgE antibodies to groups 1 and 2 of mite allergens were present in $59.0 \%$ to $70.1 \%$ of the sera, whereas $39.1 \%$ of those contained IgE to rBlo t5, 30.4\% to rBla g4, $19.9 \%$ to $\mathrm{rFel} \mathrm{d1,} 11.8 \%$ to rArt v3, $11.2 \%$ to Der p10, $9.9 \%$ to rBla g2, $9.3 \%$ to rPer a7, $9.3 \%$ to $\mathrm{nFel} \mathrm{d} 2$, and $8.7 \%$ to rCanf1. IgE antibodies to Phleum pratense, Artemisia, rCan f3, rBla g1, and rBla g5 were less prevalent (figure 4).

Regarding the results of mite-specific IgE measurements in patients with positive prick tests exclusively to one mite species, we observed that in patients with positive prick tests to Dermatophagoides and negative SPTs to Blomia tropicalis $(\mathrm{n}=14)$,

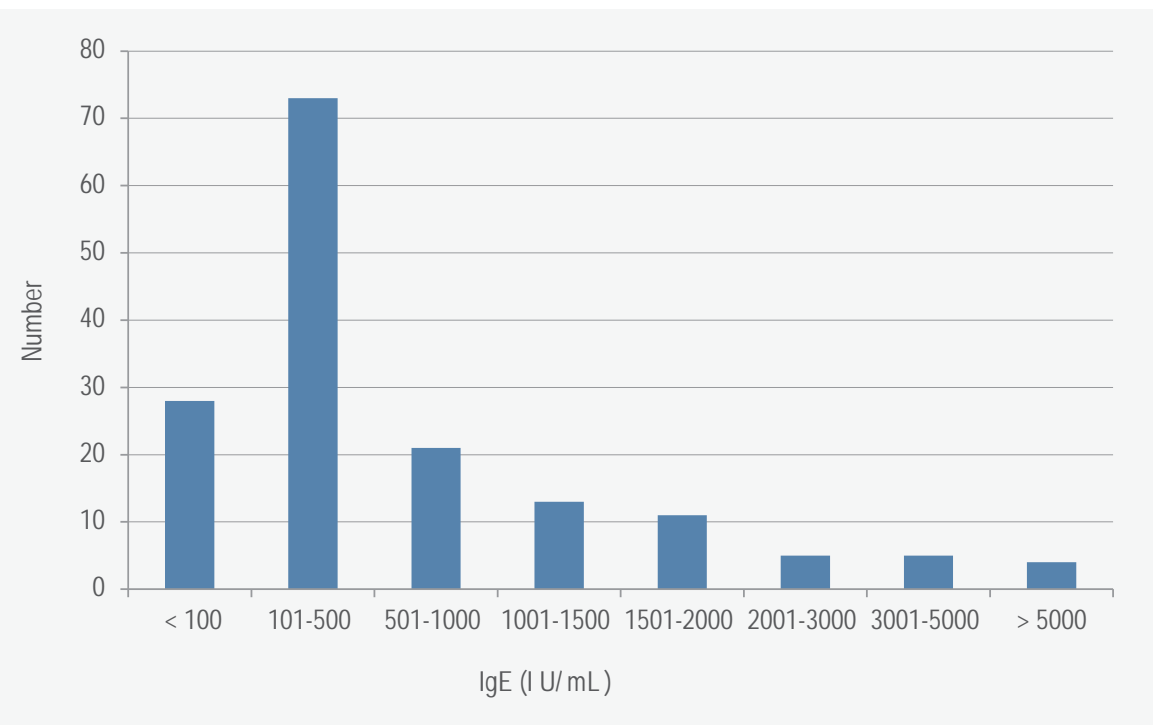

48
Figure 1. Distribution of total IgE levels in the serum of the studied patients. 
Immunoblot was positive to Dermatophagoides pteronyssinus or Dermatophagoides farinae in 12 patients, and positive to Blomia tropicalis in 5 patients. In such group, the component resolved diagnosis was positive to dermatophagoides components in 12 patients and to blo t5 in 3 patients; none of these three patients with SPTs positive to Blomia and negative to dermatophagoides had serum $\operatorname{IgE}$ antibodies, neither to dermatophagoides, nor to Blo t5 (data not shown).

Correlations between skin tests and in vitro tests There were statistically significant correlations between prick tests and specific IgE in the serum for Dermatophagoides pteronyssinus, Blomia tropicalis, and dog, whereas no significant correlations were observed for Dermatophagoides farinae, cat, and Periplaneta americana (table 2).

Regarding component resolved diagnostic testing, statistically significant correlations were present for these combinations: Dermatophagoides pteronyssinus and Der p1, Dermatophagoides pteronyssi- nus and Der p2, Dermatophagoides farinae and Der $\mathrm{f} 2$, Blomia tropicalis and Blo t5, dog and Can F1, dog and Can F3. No statistically significant correlations were found in these combinations: Dermatophagoides pteronyssinus and Der p10, Dermatophagoides farina and Der f1, cat and Fel D1, cat and Fel D2, and Periplaneta americana and Per A7 (tables 3 and 4).

\section{Discussion}

Since allergic respiratory diseases are highly prevalent in the population and lead to an impaired quality of life and a heavy burden on health systems all around the world, it is of overwhelming concern to provide better and cost effective diagnostic and therapeutic tools for its proper management. This is especially important in developing countries where health resources are limited. Few studies have investigated the profiles of allergen-specific IgE antibodies in patients from developing countries, including those located in Latin America.

The incorporation of modern methods based in the precise knowledge of allergenic epitopes of

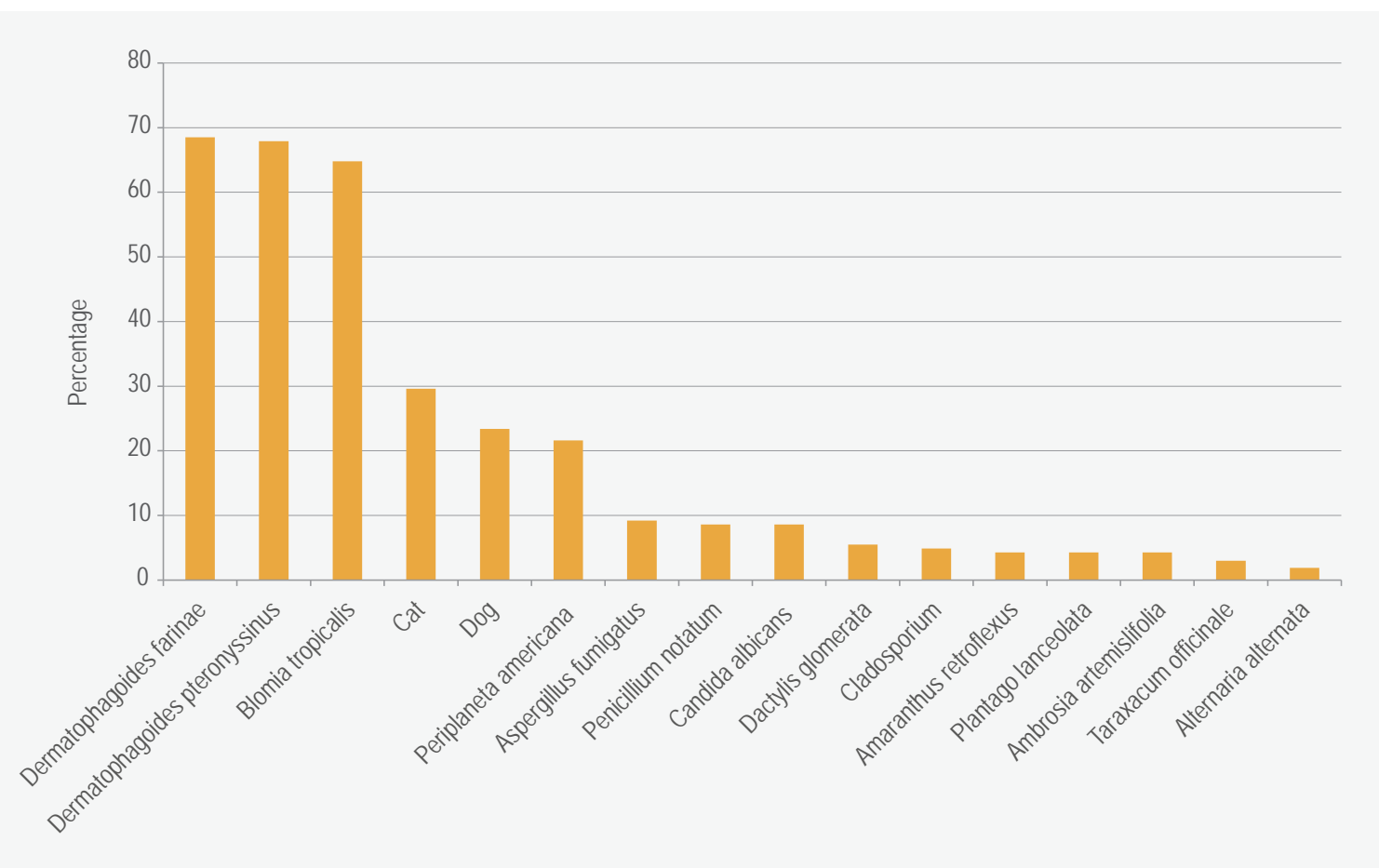

Figure 2. Results of skin prick tests with inhalant allergens expressed as the percentage of positive tests. Positive: wheal $>3 \mathrm{~mm}$ than negative control. 
common allergens provides the opportunity for improved diagnosis and possibly for the implementation of better therapies; especially molecular-based immunotherapy. The present investigation is aimed at characterizing the in vivo and in vitro $\operatorname{IgE}$ antibody responses to common environmental allergens, including allergen extracts and allergen components from inhalant allergens, in patients with rhinitis and/or asthma and to compare those responses to the results of the skin tests that were performed with commercial crude allergenic extracts.

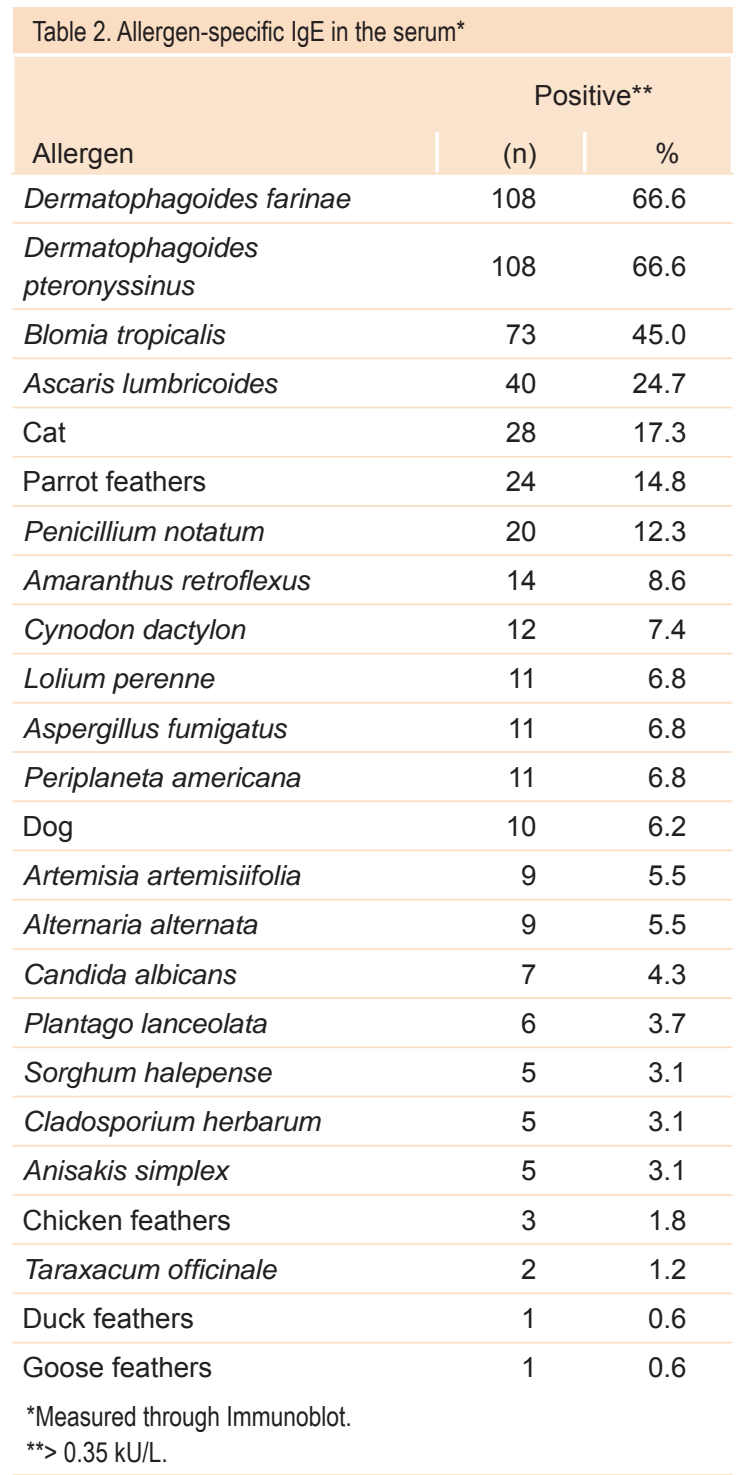

Curiously, moderate persistent rhinitis and/or moderate and uncontrolled asthma were more frequent in the studied patients. This observation is likely related to the fact that, in the present study, patients were recruited from allergy clinics, where patients are referred from general practitioners or pediatricians who lack specialized diagnostic and therapeutic resources to treat patients with more severe allergic diseases.

Increased total serum $\operatorname{IgE}$ is generally considered a diagnostic parameter for atopy in patients who are exposed to temperate climates in industrialized countries. However, in the tropics, the value of this biomarker is usually limited due to the high prevalence of intestinal helminthiasis that are able to stimulate polyclonal IgE synthesis and potentiate IgE production to environmental allergens. ${ }^{13}$ For that reason, although we did not perform coprological investigations for the presence of parasites, we measured IgE antibodies to Ascaris lumbricoides, Echinococcus granulosus, and Anisakis simplex, which were present in $24.7 \%, 7.4 \%$ and $3.1 \%$ of the patients, respectively. Zakzuk et al. observed the presence of ascaris-specific $\operatorname{IgE}$ in the serum in $26.5 \%$ of young children from Cartagena, Colombia. ${ }^{14}$ We postulate that increased total IgE levels in our patient's sera could be attributed to past or current helminth infestations in at least one quarter of the patients, whereas, in the remaining $75 \%$, those results would be more likely related to the atopic condition or other etiologies. This hypothesis finds support in the presence of a statistically significant correlation between total serum $\operatorname{IgE}$ and positive ascaris-specific IgE in the serum (figure 4). In consequence, in the absence of past or current intestinal helminthiasis, especially in patients from a higher socioeconomic status, levels of IgE could be useful markers for suspecting atopic disease even in tropical environments.

Skin prick tests to mite allergen extracts were positive in a large proportion of our patients; followed by cat, dog, and American cockroach. These results confirm previous observations ${ }^{4,5,6}$ and suggest that, in Caracas, where no major seasonal climatic variations are present, pollen and mould allergens would not be frequent etiologic factors of allergic respiratory diseases in most of the patients. It must be taken into account that, in Caracas, there are only two major seasons; a dry season running from De- 
cember to April, and a rainy or humid season which is present between May and November. Then, with seasonal variations, mild and allergic diseases tend to be perennial (persistent) instead of seasonal (intermittent).

The results of prick tests were confirmed by measurement of allergen-specific serum IgE through enzyme-linked immunoblot tests with crude allergens since, once again, mites predominated as the main cause of allergic sensitization, followed by cat, dog, and, at a lesser degree, bird feathers and moulds. A major discrepancy was observed between positive skin tests and in vitro IgE levels to American cockroach $(21.6 \%$ for prick tests versus $6.8 \%$ for in vitro tests), while low proportions of patients showed serum IgE to the investigated pollens.

Jimenez et al. described increased levels of specific IgE to Dermatophagoides pteronyssinus in $86.6 \%$ and to Blomia tropicalis in $84.4 \%$ of asthmatic patients from Cartagena, Colombia. ${ }^{15}$ These values are higher than those that are observed in the current study. In Singaporean children with allergies, Kidon et al. observed sensitization rates of $89 \%$ for Dermatophagoides pteronyssinus and $70 \%$ for Blomia tropicalis, ${ }^{16}$ and, in 3-year-olds, Zakzuk et al. observed rates of $18.6 \%$ for Dermatophagoides pteronyssinus and $33.3 \%$ for Blomia tropicalis. ${ }^{14}$

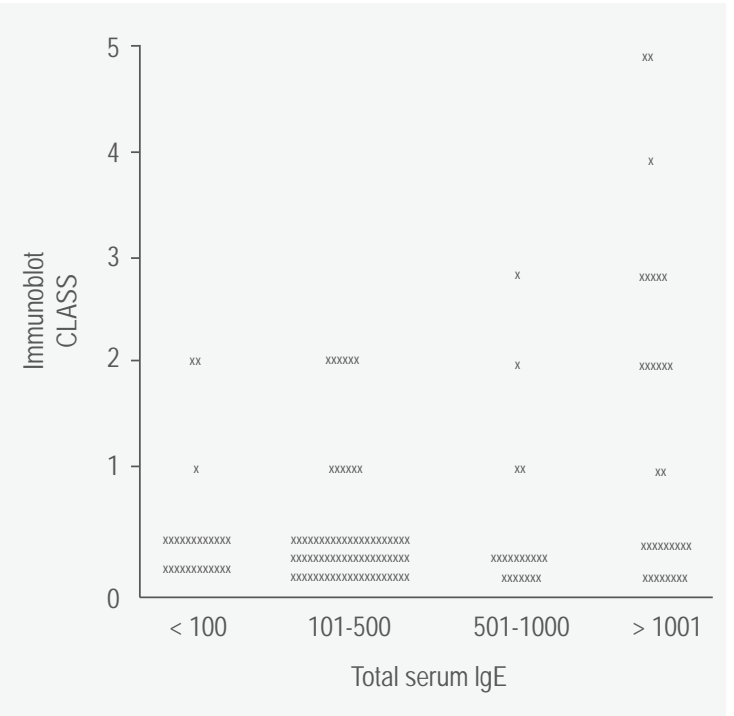

Figure 3.Correlation between total serum $\lg E$ and specific $\lg \mathrm{E}$ to Ascaris lumbricoides $(r=0.5, p<0.05)$.

The results of tests for specific $\operatorname{IgE}$ to allergenic components were compatible with the results of skin tests and immunoblot with crude allergens since specific $\operatorname{IgE}$ antibodies to group 1 and 2 mite allergens, Blo t5, Bla g4, and Fel d1 were present with

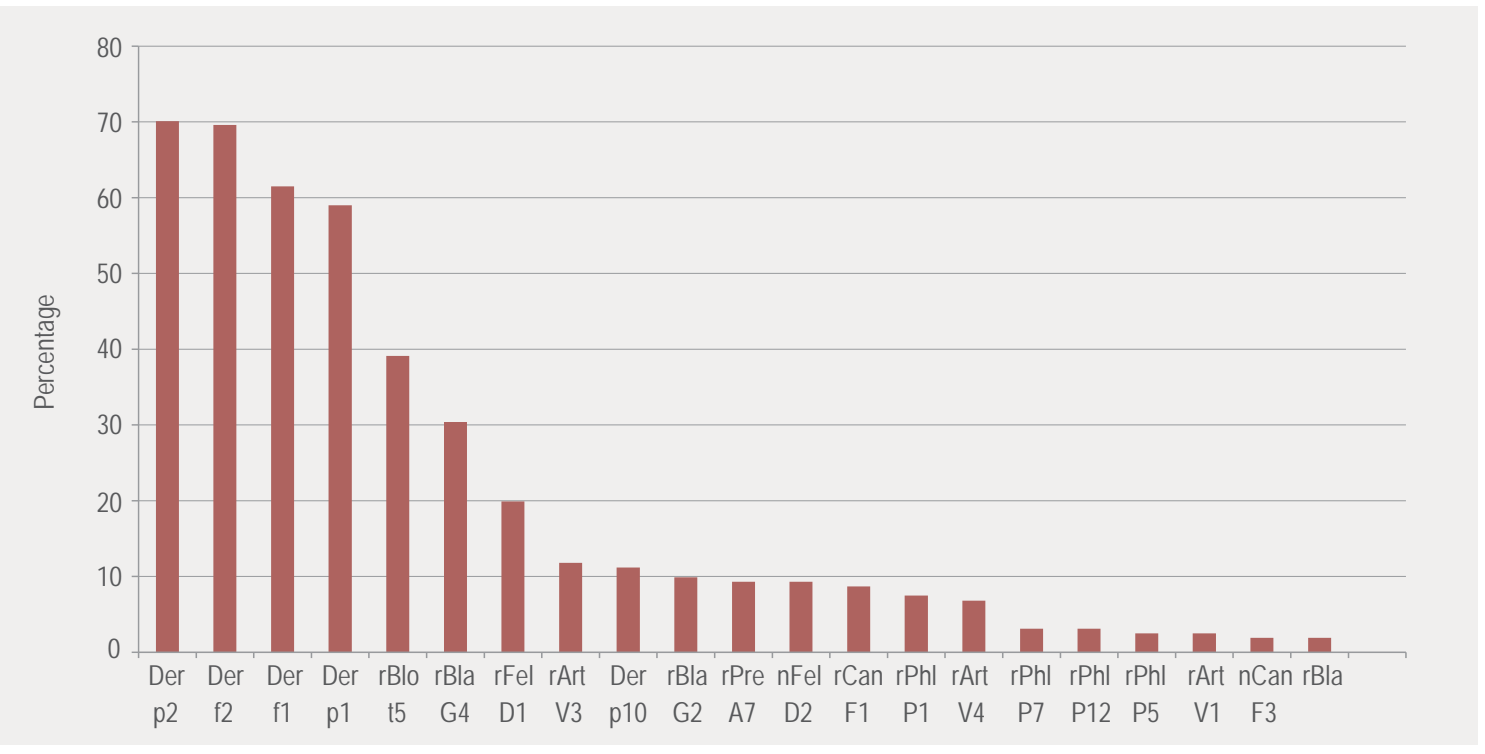

Figure 4. Specific IgE to allergen components. 


\begin{tabular}{|c|c|c|c|}
\hline Allergen & $\begin{array}{c}\text { Correlation } \\
\text { coefficient }(r)^{\&}\end{array}$ & $\begin{array}{l}\text { Confidence } \\
\text { interval }\end{array}$ & $\mathrm{p}$ \\
\hline Dermatophagoides pteronyssinus & 0.26 & $0.08-0.43$ & $<0.05$ \\
\hline Dermatophagoides farinae & 0.16 & $-0.02-0.34$ & NS \\
\hline Blomia tropicalis & 0.43 & $0.26-0.57$ & $<0.05$ \\
\hline Dog & 0.39 & $0.08-0.63$ & $<0.05$ \\
\hline Cat & 0.05 & $-0.23-0.33$ & NS \\
\hline Periplaneta americana & -0.11 & $-0.43-0.22$ & NS \\
\hline \multicolumn{4}{|c|}{$\begin{array}{l}\text { *Skin prick tests: positive } \geq 3 \mathrm{~mm} \text {. *} \mid \text { mmunoblot assay. } \\
\text { \&Pearson's correlation coefficient. } \\
\text { NS = not sianificant }\end{array}$} \\
\hline
\end{tabular}

more frequency. These data are quite like the results of Jimenez et al. ${ }^{14}$ and Kidon et al. ${ }^{16}$ concerning specific IgE to Der p2, Der p1 and Der p10. Once again, IgE antibodies to pollen components from Phleum pratense and Artemisia vulgaris were less prevalent.

Blo 5 and Blo 21 have been proposed as the specific non cross-reacting major allergenic components involved in sensitization to Blomia tropicalis. In a previous study, it was found that positive prick tests to Der p5 were present in $38.0 \%$, and to Blo t5 in $42.4 \%$ of 92 allergic patients; in that study, the rates of positive skin tests and the mean wheal sizes induced by Derp5 and Blo t5 were significantly lower than the responses to the natural extracts of both Dermatophagoides pteronyssinus and Blomia tropicalis. ${ }^{17}$

The prevalence of allergic sensitization to Blo t5 in our allergic population, as determined by quantification of specific IgE, is close to what has been reported in Cartagena, Colombia (42.2\%, $59.6 \%$ and $51 \%),{ }^{15}$ and Singapore $(45 \%) .{ }^{16}$ The observed rate of positivity of prick tests to Blomia tropicalis extract in $64.8 \%$ of the studied population is likely due to cross-reactions between allergen components that are present in the Blomia

\begin{tabular}{|c|c|c|c|}
\hline Allergen-component & $\begin{array}{l}\text { Correlation } \\
\text { coefficient }(r)^{2}\end{array}$ & $\begin{array}{l}\text { Confidence } \\
\text { interval }\end{array}$ & $p$ \\
\hline Dermatophagoides pteronyssinus-Der $\mathrm{p} 1$ & 0.27 & $0.08-0.43$ & $<0.05$ \\
\hline Dermatophagoides pteronyssinus-Der p2 & 0.33 & $0.15-0.48$ & $<0.05$ \\
\hline Dermatophagoides pteronyssinus-Der p10 & 0.01 & $-0.17-0.20$ & NS \\
\hline Dermatophagoides farinae-Der f1 & 0.01 & $-0.17-0.20$ & NS \\
\hline Dermatophagoides farinae-Der f2 & 0.25 & $0.06-0.41$ & $<0.05$ \\
\hline Blomia tropicalis-rBlo t5 & 0.29 & $0.10-0.46$ & $<0.05$ \\
\hline Cat- rFel D1 & -0.03 & $-0.31-0.25$ & NS \\
\hline Cat- rFel D2 & 0.03 & $-0.25-0.31$ & NS \\
\hline Dog- rCan F1 & 0.38 & $0.07-0.62$ & $<0.05$ \\
\hline Dog- nCan F3 & 0.43 & $0.13-0.66$ & $<0.05$ \\
\hline Periplaneta americana-rPer A7 & 0.23 & $-0.11-0.52$ & NS \\
\hline
\end{tabular}


tropicalis extract, which are shared by other mites, including Dermatophagoides spp.

A group of allergic patients who reacted exclusively to Blomia tropicalis and did not react to dermatophagoides on the skin test was previously described. This group represents about $12.5 \%$ of our allergic patients, ${ }^{18}$ confirming other observations from Venezuela ${ }^{19}$ and Colombia, ${ }^{15}$ where 10 $11 \%$ and $8-9 \%$ of the patients, respectively, reacted exclusively to blomia extract. In our current study, $8.5 \%$ of the patients showed positive SPTs to dermatophagoides associated with negative tests to Blomia tropicalis, and this observation could be confirmed in vitro in most of the patients. However, in three patients with positive SPTs to Blomia tropicalis and, negative tests to dermatophagoides serum specific IgE antibodies to Dermatophagoides spp. and Blomia tropicalis were not demonstrated.

Der p10, tropomyosin, is also an interesting topic interesting to be discussed; since this allergen has been involved in cross-reactions between mites, cockroaches, helminths, and crustaceans. Specific IgE to Der p10 was present in only $11.2 \%$ of the patients, compared to a prevalence of $16.7 \%$ in Cartagena, ${ }^{15}$ and indicating that such cross reactivity isn't highly prevalent in our patients.

The results of the present study that confirm the importance of mite allergens as a major etiologic factor of rhinitis and asthma in allergic patients living in a tropical environment are important since it has been postulated that Dermatophagoides pteronyssinus and Blomia tropicalis are the most prevalent domestic mites of the tropical and subtropical regions where allergic sensitization to those mites is very high. ${ }^{18,20,21,22,23}$

Limitations to the present study include the cross-sectional design of the investigation, and possibly a referral bias since patients were recruited exclusively from allergy clinics which were attended mostly by patients with moderate/severe allergic rhinitis or asthma and, in consequence, its results cannot be extrapolated to the whole population of allergic patients who have been treated by other non-specialist physicians. The statistically significant correlations between the skin test results and in vitro specific IgE, which are present for some of the tested allergens or components, are like those observed in a recent study by Chauveau et al., in which a moderate agreement between those two parameters was present in a group of 10 -year-olds. ${ }^{23}$

\section{Acknowledgements}

Authors acknowledge Byo Latin America for partial financial support for this study. We thank Mr. Pedro J. Ovalles for the statistical data analysis.

\section{Financial support}

Partially supported by Byo Latin America and Euroimmun, Lübeck, Germany.

\section{References}

1. Pawankar R, Sánchez-Borges M, Bonini S, Kaliner M. The Burden of Allergic Disease. Allergic Rhinitis, Allergic Conjunctivitis, and Rhinosinusitis. In: WAO. White Book on Allergy. USA: World Allergy Organization; 2011.

2. Holgate ST, Canonica GW, Baena-Cagnani CE, Casale TB, Zitt M, Nelson H, et al. Asthma. In: WAO. White Book on Allergy. USA: World Allergy Organization; 2011.

3. Chong-Neto HJ, Rosario NA, Solé D, Latin American ISAAC Group. Asthma and rhinitis in South America: how different they are from other parts of the world. Allergy Asthma Immunol Res. 2012;4(2):62-67. DOI: 10.4168/aair.2012.4.2.62

4. Sánchez-Borges M, Mantilla P, Capriles-Hulett A, Caballero-Fonseca F. Alérgenos responsables de las enfermedades alérgicas respiratorias en Venezuela. Rev Ven Alerg Asma Inmunol. 2003;2:43-52.

5. Sánchez-Borges M, Capriles-Hulett A, Caballero-Fonseca F, Fernández-Caldas E. Mite and cockroach sensitization in allergic patients from Caracas, Venezuela. Ann Allergy Asthma Immunol. 2003;90(6):664668. DOI: 10.1016/S1081-1206(10)61873-X

6. Sánchez-Borges M, Fernández-Caldas E, Capriles-Hulett A, Caballero-Fonseca F. Mite hypersensitivity in patients with rhinitis and rhinosinusitis living in a tropical environment. Allergol Immunopathol (Madr). 2014;42(2):120-126. DOI: 10.1016/j.aller.2012.07.011 
7. Corren J, Baroody FM, Pawankar R. Allergic and nonallergic rhinitis. In: Franklin-Adkinson N, Bochner BS, Wesley-Burks A, Busse WW, Holgate ST, Lemanske RF, et al. Middleton's Allergy. Principles and practice. USA: Elsevier Saunders; 2014.

8. Guilbert TW, Lemanske RF, Jackson DJ. Diagnosis of asthma in infants and children. In: FranklinAdkinson N, Bochner BS, Wesley-Burks A, Busse WW, Holgate ST, Lemanske RF, et al. Middleton's Allergy. Principles and practice. USA: Elsevier Saunders; 2014.

9. Boulet LP. Diagnosis of asthma in adults. In: Franklin-Adkinson N, Bochner BS, Wesley-Burks A, Busse WW, Holgate ST, Lemanske RF, et al. Middleton's Allergy. Principles and practice. USA: Elsevier Saunders; 2014.

10. Canonica GW, Ansotegui IJ, Pawankar R, Schmid-Grendelmeier P, Van-Hage M, Baena-Cagnani CE, et al. A WAO-ARIA-GA2LEN consensus document on molecular-based allergy diagnostics. World Allergy Organ J. 2013;6(1):17. DOI: 10.1186/1939-4551-6-17

11. Brozek JL, Bousquet J, Agache I, Agarwal A, Bachert C, Bosnic-Anticevich S, et al. Allergic Rhinitis and its Impact on Asthma (ARIA) guidelines: 2016 revision. J Allergy Clin Immunol. 2017;140(4):950-958. DOI: 10.1016/j.jaci.2017.03.050

12. Global initiative for asthma. Global strategy for asthma management and prevention. Canadá: Global Initiative for Asthma; 2014.

13. Acevedo N, Caraballo L. IgE cross-reactivity between Ascaris lumbricoides and mite allergens: possible influences on allergic sensitization and asthma. Parasite Immunol. 2011;33(6):309-321. DOI: 10.1111/j.1365-3024.2011.01288.x

14. Zakzuk J, Acevedo N, Cifuentes L, Bornacelly A, Sánchez J, Ahumada V, et al. Early life responses in children living in the tropics: a prospective analysis. Pediatr Allergy Immunol. 2013;24(8):788-797. DOI: 10.1111/pai.12161

15. Jimenez J, Puerta L, Mendoza D, Chua KY, Mercado D, Caraballo L. IgE antibody responses to recombinant allergens of Blomia tropicalis and Dermatophagoides pteronyssinus in a tropical environment. Allergy Clin Immunol Int. 2007;19(6):233-239. DOI: 10.1027/0838-1925.19.6.233

16. Kidon MI, Wen Chin C, Kang LW, Ching OT, Seng TY, Ning WK, et al. Mite component-specific IgE repertoire and phenotypes of allergic disease in childhood: the tropical perspective. Pediatr Allergy Immunol. 2011;22(2):202-210. DOI: 10.1111/j.1399-3038.2010.01094.x

17. Caballero F, Sánchez-Borges M, Bernstein M, Aldrey O, Chapman M, Fernández-Caldas E. Skin test reactivity to natural and recombinant mite allergens. J Allergy Clin Immunol. 2000;105(1 Pt 2):S327.

18. Capriles-Hulett A, Iraola V, Pinto H, Sánchez-Borges M, Daboín-De-Veer M, Fernández-Caldas E. Monosensitization to Blomia tropicalis: is exposure the only factor involved? J Investig Allergol Clin Immunol. 2009;19(2):165-166.

19. Puccio F, Lynch NR, Noya O, Noda A, Hagel I, López E, et al. Importance of including Blomia tropicalis in the routine diagnosis of Venezuelan patients with persistent allergic symptoms. Allergy. 2004;59(7):753757. DOI: 10.1111/j.1398-9995.2004.00454.x

20. Sánchez-Borges M, Fernández-Caldas E, Thomas WR, Chapman MD, Lee BW, Caraballo L, et al. International Consensus (ICON) on: Clinical consequences of mite hypersensitivity: a global problem. WAO J. 2017;10:14.

21. Fernandez-Caldas E, Puerta L, Mercado D, Lockey RF, Caraballo L. Mite fauna, Der p1, Der f1, and Blomia tropicalis allegen levels in a tropical environment. Clin Exp Allergy. 1993;23:292-297. DOI: 10.1186/s40413-017-0145-4

22. Zhang L, Chew FT, Soh SY, Yi FC, Law SY, Goh DY, et al. Prevalence and distribution of indoor allergens in Singapore. Clin Exp Allergy. 1997;27(8):876-885. DOI: 10.1111/j.1365-2222.1997.tb01227.x

23. Chauveau A, Dalphin ML, Mauny F, Kaulek V, Schmausser-Hechfellner E, Renz H, et al. Skin prick tests and specific IgE in 10-year-old children: agreement and association with allergic diseases. Allergy. 2017;7(9)2:1365-1373. DOI: 10.1111/all.13148 